\title{
Microanatomy and histomorphometry analysis of the effects of Moringa oleifera leaf extract on lead-induced kidney damage in adult wistar rats
}

\author{
Sunday Yinka OLATUNJI ${ }^{1,2^{*}}$, Olarinde Stephen ADEWOLE ${ }^{1}$, \\ Olugbenga Ayodeji AYANNUGA ${ }^{1}$, Adelodun Steiphen TAIYE ${ }^{1}$, \\ Adekomi Damilare ADEDAYO ${ }^{1,3}$ and Olukiran Olaoluwa SESAN ${ }^{4}$ \\ ${ }^{I}$ Department of Anatomy and Cell Biology, Obafemi Awolowo University, Ile-Ife, Nigeria. \\ ${ }^{2}$ Department of Anatomy, Ben Carson Senior School of Medicine, Babcock University, Ilisan Remo, Nigeria. \\ ${ }^{3}$ Department of Anatomy, Ekiti State University, Ado-Ekiti, Nigeria. \\ ${ }^{4}$ Department of Physiological Sciences, Obafemi Awolowo University, Ile-Ife, Nigeria. \\ *Corresponding author,E-mail: adajosunday@yahoo.com,olatunjis@babcock.edu.ng; \\ Tel: +2348069019522. P.M.B.5559 Lagere, Ile-Ife Osun State, Nigeria.
}

\begin{abstract}
This study evaluated the effects of lead exposure on the histoarchitecture of kidney, assessed the effects of lead on the levels of creatinine, urea and albumin in the plasma and determined the effects of M. oleifera leaf extract (MOLE) on the histoarchitecture of kidney in Wistar rats after lead-induced kidney damage. This was with a view to providing information on the ameliorative effects of $M$. oleifera leaf extract on lead-induced kidney damage. Thirty adult male Wistar rats weighing 120 - $180 \mathrm{~g}$ were used for this study. Kidney damage was experimentally induced by daily administration of lead acetate $(50 \mathrm{mg} / \mathrm{kg} / \mathrm{day})$ for a period of 14 days. The test groups were treated with the $M$. oleifera leaf extract $(100 \mathrm{mg} / \mathrm{kg} / \mathrm{day})$ for 14 days. At the end of treatment period, the rats were sacrificed and their kidneys were excised for histological and histomorphometric studies. Markers of renal function were biochemically determined in the plasma using enzyme calorimetric assay kit. Histomorphological examinations of the stained kidney sections revealed that $100 \mathrm{mg} / \mathrm{kg}$ of MOLE had no adverse effects on the kidney of group $\mathrm{C}$ rats as the morphology of kidney of the rats in this group were normal and comparable with that of groups A and B. However, deleterious effects such as distortion of Bowman's capsule with diminished glomerular space, structural alteration of proximal and distal convoluted tubules were observed in the kidney of group D rats following lead-induced damage. Treatment with MOLE protected the kidneys of groups $\mathrm{E}$ and $\mathrm{F}$ rats from lead-induced damage as the renal morphology appeared normal. The results of biochemical analysis revealed a significant increase in the plasma level of urea $(\mathrm{F}=203.9, \mathrm{p}=$ $0.0001)$, and creatinine $(\mathrm{F}=7.42, \mathrm{p}=0.0002)$, in group $\mathrm{D}$ rats $(56.79 \pm 0.06 \mathrm{~g} / \mathrm{l}, 2.91 \pm 0.07 \mathrm{mg} / \mathrm{dl})$, respectively compared with groups A $(14.02 \pm 1.53 \mathrm{~g} / \mathrm{l}, 2.33 \pm 0.06 \mathrm{mg} / \mathrm{dl}), \mathrm{B}(50.44 \pm 1.75 \mathrm{~g} / \mathrm{l}, 2.54 \pm 0.06$ $\mathrm{mg} / \mathrm{dl}), \mathrm{C}(58.91 \pm 2.95 \mathrm{~g} / \mathrm{l}, 2.42 \pm 0.11 \mathrm{mg} / \mathrm{dl}), \mathrm{E}(12.18 \pm 1.45 \mathrm{~g} / \mathrm{l}, 2.45 \pm 0.08 \mathrm{mg} / \mathrm{dl})$ and F $(7.48 \pm 1.00 \mathrm{~g} / \mathrm{l}, 2.39$ $\pm 0.08 \mathrm{mg} / \mathrm{dl}$ ) respectively. This is an indication of impaired renal function. Also, the results of the histomorphometry analysis showed a significant decrease in the number of glomeruli present in each photomicrograph and the diameter of the urinary space in group D respectively compared with groups A, B, C, E and F. This study showed that treatment with Moringa oleifera prevented the toxicity brought about by lead exposure and this is evidenced by an enhancement in the glomerular morphology and clearly seen renal tubules. In conclusion, our findings suggest that Moringa oleifera leaf extract had ameliorative and protective properties on lead-induced kidney injury.
\end{abstract}

(C) 2015 International Formulae Group. All rights reserved.

Keywords: Nephrotoxicity, lead acetate, renal, prophylactic. 


\section{INTRODUCTION}

Lead $(\mathrm{Pb})$ is a highly toxic metal with no known physiological benefits and is a global pollutant in the ecosystem as a result of its natural occurrence and its industrial use (Ahmed et al., 2008). It can be found in many products and locations which includes paint, dust, soil, drinking water, air, cosmetics, lead-glazed ceramics, imported candies and food, firearms with lead bullets, car batteries, radiators, and some inks. All these products and locations are various ways by which humans are exposed to lead (Ahmed et al., 2008). Exposure to this highly toxic substance can result in a wide range of adverse health effects on the nervous system, kidneys, reproductive system, hepatic, hearing, endocrine, gastrointestinal and cardiovascular system (Robert and Thomas, 2001).

Moringa oleifera (Lam) (Moringaceae) is a highly valued plant, distributed in many countries of the tropics and subtropics. It has an impressive range of medicinal uses with high nutritional value. M. oleifera is very important for its medicinal value (Anwar et al., 2007). Various parts of this plant, such as the leaves, roots, seed, bark, fruit, flowers and immature pods act as cardiac and circulatory stimulants, possess antitumor, antipyretic, antiepileptic, anti-inflammatory, antiulcer, antispasmodic, diuretic, antihypertensive, cholesterol lowering, antioxidant, antidiabetic, hepatoprotective, antibacterial and antifungal activities, and are being employed for the treatment of different ailments in the indigenous system of medicine (Anwar et al., 2007). The usefulness of the kidney in our body cannot be overemphasized. Its major roles are to maintain internal environment which allow maximum cellular function as well as to remove toxic substances that are generated by metabolism (Sembulingam, 2012). Nephrotoxicity is a poisonous effect of some substances such as toxic chemicals and medication, on the kidney. Most kidney diseases attack the nephrons, altering their ability to filter blood and produce urine (Guyton and Hall, 2006). Thus research efforts towards limiting these consequences are ongoing. Nigerian children are prone to lead exposure and poisoning in their homes due to the occupation of their parents. An example of this is the case of lead poisoning in Zamfara, Nigeria. This lead to the death of several children up to the age of 5 as a result of playing on leaded soil where lead rich gold ore is processed in households (Lo et al., 2012). In addition, Pfitzner et al. (2000) observed increased blood lead levels in children who live in battery smelting area and in some geographical locations in Nigeria. In Nigeria, the amount of lead in canned and uncanned consumer products is a cause for concern as a study revealed that all the canned beverages analyzed had lead levels beyond the maximum contaminant level of 0.002 to $0.0073 \mathrm{mg} / \mathrm{L}$, while $73.9 \%$ of uncanned beverages had lead levels beyond the maximum contaminant level of 0.001 to 0.092 $\mathrm{mg} / \mathrm{L}$ (Maduabuchi et al., 2006). In addition to this, it was discovered from a study in Abeokuta Nigeria that the lead levels in smoked fish is increased by seven times due to the technique used in its processing (Adekunle and Akinyemi, 2004). Also, there is consumption of lead and other heavy metals in prepared herbal medicine in Nigeria due to poverty and lack of knowledge of conventional medical care products (Nnorom et al., 2006). Furthermore, lead levels beyond the maximum contaminant level have been discovered in some sachet water (Orisakwe et al., 2006). Consuming meat from game birds killed with lead bullet is known to cause poor academic performance in children, and miscarriage in pregnant women (Green and Pain, 2012). Lead consumption through the 
diet in Nigerian may have adverse health effects on the body especially in children whose body and immune system are just building up (Ajayi et al., 2014). Many medicinal plants have been shown to have ameliorative effects on nephrotoxicity. However, this study will investigate the effects of Moringa oleifera leaf extract on the microanatomy and histomorphometry analysis of the kidney of Wistar rats damaged with lead, with a view to evaluating the histoarchitectural effects of lead exposure on the kidney and assess the effects of lead on some renal function parameters (creatinine, urea and albumin). The findings from this study will provide information on the effects of lead acetate exposure on the kidney and also on the possible ameliorative effects of $M$. oleifera leaf extract on the lead-induced kidney damage.

\section{MATERIALS AND METHODS}

\section{Plant extract}

Moringa oleifera leaves were plucked

from Seventh-Day Adventist Hospital compound in Ile- Ife and were taken to a taxonomist at the Department of Botany, Obafemi Awolowo University, Ile-Ife, Nigeria, for authentication after which a voucher specimen was deposited at Ife Herbarium for reference with a reference number 17007. The plant was air-dried and ground to powder using an electric grinder. The powder was extracted with ethanol for 24 hours. The extract was filtered and the filtrate was concentrated at $30{ }^{\circ} \mathrm{C}$ using the vacuum rotary evaporator to completely remove the ethanol. The ethanolic extract was stored in a desiccator until used.

\section{Animals}

Thirty adult male Wistar rats weighing between 120-180 $\mathrm{g}$ were obtained from the Animal Holding of the Department of
Anatomy and Cell Biology, Faculty of Basic Medical Sciences, Obafemi Awolowo University, Ile-Ife and used for this research. The rats were randomly assigned into six groups of five rats per group (Groups A, B, C, $\mathrm{D}, \mathrm{E}$ and F). Animals were housed in clean plastic cages under natural light and dark cycles and at room temperature. Animals in all groups fed on normal laboratory chow ad libitum, and had free access to water. Treatment protocol

The following treatment protocol was employed for this study.

Group A: Control, rats received distilled water only;

Group B: Tween 20 fluid solution (100 $\mathrm{mg} / \mathrm{kg}$ body weight) (1\%) only;

Group C: M. oleifera $(100 \mathrm{mg} / \mathrm{kg}$ body weight) only;

Group D: Lead acetate $(50 \mathrm{mg} / \mathrm{kg}$ body weight) only;

Group E: lead acetate $(50 \mathrm{mg} / \mathrm{kg}) \quad 14$ days + M. oleifera $(100 \mathrm{mg} / \mathrm{kg}) 14$ days;

Group F: M. oleifera (100 mg/kg) 14 days + Lead acetate $(50 \mathrm{mg} / \mathrm{kg}) 14$ days; M. oleifera extract (100 mg/kg body weight) was dissolved in $1 \%$ tween 20 fluid and lead acetate $(50 \mathrm{mg} / \mathrm{kg}$ body weight) (Owolabi et al., 2012) dissolved in distilled water were administered daily, orally for the period of administration using suitable oral cannula. Lead acetate was obtained from Sigma Chemicals, USA.

\section{Measurement of body weight, water intake and food consumption}

The animals' body weight were measured daily throughout the period of administration (using Camry weighing balance, China) to access the weight gain or loss in each group. Water intake and food consumption of each group were determined daily from the onset of the experiment. The volume of water and quantity of food given to 
each group of rats were measured with a measuring cylinder and a weighing balance respectively. The volume of the left-over water and food overnight were also measured. The difference between the previous day volume of water and weight of food and the left-over was taken as the daily food consumption and water intake of the group.

\section{Sacrifice and organ harvest}

Twenty four (24) hours after the last administration, the animals were sacrificed by cervical dislocation method. The blood samples were collected from the animals through cardiac puncture and were stored in EDTA tubes. An abdominal incision was made to expose the content of the abdominal cavity; the intestines and other abdominal organs were displaced using the forceps and a pair of kidneys on the posterior abdominal wall was located. The excised kidneys were fixed in $10 \%$ formol saline for 24 hours and then processed for histological demonstrations.

\section{Histology and histomorphometry analysis}

Haematoxylin and Eosin method was used to demonstrate the general histology and morphology of the kidney (Anthony, 2010) of the control and treated groups. The sections were examined under a LEICA research microscope (LEICA DM750, Switzerland) interfaced with digital camera (LEICA ICC50). Digital photomicrographs of stained sections of the kidney structure were taken at various magnifications.

Photomicrographs of haematoxylin and eosin stained sections were imported on to the Motic Images Plus version 2.0 software for histomorphometric analysis, to calculate the number of glomeruli present in each photomicrograph, at $\mathrm{x} 10$ magnification, diameter of the urinary space and cross sectional area of the glomerulus and tubules (both the proximal and distal convoluted tubules) and at x40 magnification.

$\mathrm{D}_{1}=$ minimum diameter

$\mathrm{D}_{2}=$ maximum diameter

Diameter $(D)=\sqrt{ }\left(D_{1} \times D_{2}\right)$

Cross sectional area $=\pi \mathrm{D} 2 / 4$

About $5 \mathrm{ml}$ of whole blood collected into an EDTA tube and later centrifuged at $4000 \mathrm{rpm}$ for 15 minutes using Bench Centrifuge (Model 800D, Lincoln Mark Medical; England). The plasma was separated and analyzed for renal functions test with investigation of creatinine, urea and albumin.

\section{Statistical analysis}

Data were expressed as Mean \pm Standard Error of Mean (S.E.M). The statistical significant was evaluated by one way analysis of variance (ANOVA) using GraphPad Prism5 (Version 5.03, GraphPad Inc.) followed by Student Newan-Keuls (SNK) test for multiple comparisons. A value of $p<0.05$ was considered statistically significant.

\section{RESULTS}

\section{Body weight}

Table 1 shows that while there was an increase in body weight in both the control and the treated groups, the weight gain in the control was significantly higher compared with all the treated groups. No significant difference was observed between all the treated groups when compared with each other.

\section{Food intake of rats in the first week of treatment}

As shown in Table 2, there was significant decrease in the food intake of the control when compared to the treatment groups. There was no significant difference in the food intake of the treatment groups when compared with each other. 
Food intake of rats in last week of treatment

During the last week of the experiment, the food consumption in the control group was significantly $(\mathrm{p}<0.05)$ higher when compared with groups $\mathrm{D}(\mathrm{Pb}), \mathrm{E}(\mathrm{Pb}+\mathrm{MO})$, and $\mathrm{F}$ $(\mathrm{MO}+\mathrm{Pb})$. No significant $(\mathrm{p}>0.05)$ difference was observed between group A (control, distilled water), group B (tween 20) and group C (MO), respectively. However, group D shows a sharp significant decrease in food intake when compared with groups B (tween 20) and C (MO). No significant difference was observed between $\mathrm{D}(\mathrm{Pb}), \mathrm{E}$ $(\mathrm{Pb}+\mathrm{MO})$ and $\mathrm{F}(\mathrm{MO}+\mathrm{Pb})$. Also, when comparing the food consumption of the animals during the first and the last week of the experiment, the food intake during the first week was significantly $(p<0.05)$ higher than the last week of experiment.

\section{Water intake of rats in the first week of treatment}

Table 3 shows the water intake of the animal in both the control and treated groups during the first week and the last week of experiment. There was no significant difference between the control, B (tween 20) and $\mathrm{C}$ (MO) groups. However, the control group was highly significant in water intake when compared with group $\mathrm{D}(\mathrm{Pb}), \mathrm{E}(\mathrm{Pb}$ $+\mathrm{MO})$ and $\mathrm{F}(\mathrm{MO}+\mathrm{Pb})$ respectively. Groups B (tween 20) and C (MO) showed significant increase in water intake when compared with $\mathrm{D}(\mathrm{Pb}), \mathrm{E}(\mathrm{Pb}+\mathrm{MO})$ and $\mathrm{F}(\mathrm{MO}+\mathrm{Pb}) . \mathrm{F}$ $(\mathrm{MO}+\mathrm{Pb})$ was highly significant in water intake compared with $\mathrm{D}(\mathrm{Pb})$, and $\mathrm{E}(\mathrm{Pb}$ $+\mathrm{MO})$.

Water intake of rats in the last week of experiment

Water intake in the last week of experiment in control group was significantly $(\mathrm{p}<0.05)$ higher compared with groups D
$(\mathrm{Pb}), \mathrm{E}(\mathrm{Pb}+\mathrm{MO})$ and $\mathrm{F}(\mathrm{MO}+\mathrm{Pb})$ but significantly lower compared with $\mathrm{B}$ (tween 20). There were significant increase in water intake in $\mathrm{B}$ (tween20) and $\mathrm{C}$ (MO) compare with $\mathrm{D}(\mathrm{Pb}), \mathrm{E}(\mathrm{Pb}+\mathrm{MO})$ and $\mathrm{F}(\mathrm{MO}+\mathrm{Pb})$. The water intake in $\mathrm{D}(\mathrm{Pb})$ was significantly lower compared with $\mathrm{E}(\mathrm{Pb}+\mathrm{MO})$ and $\mathrm{F}$ $(\mathrm{MO}+\mathrm{Pb})$. There was no significant difference between water intake in groups $\mathrm{E}(\mathrm{Pb}+\mathrm{MO})$ and $\mathrm{F}(\mathrm{MO}+\mathrm{Pb})$. Also, when comparing the water intake of the animals during the first and the last week of the experiment, the water intake during the first week was significantly higher than the last week of experiment.

\section{Plasma creatinine level in rat after treatment}

As shown in Figure 1, the plasma creatinine level in control group $(2.33 \pm 0.06)$ was significantly $(\mathrm{p}<0.05)$ lower compared to group $\mathrm{D}(\mathrm{Pb})(2.91 \pm 0.07)$. Also when comparing all the treated groups, plasma creatinine level in group $\mathrm{D}(\mathrm{Pb})(2.91 \pm 0.07)$ was significantly higher than groups B $(2.54 \pm$ $0.06), \mathrm{C}(2.42 \pm 0.11), \mathrm{E}(2.45 \pm 0.08)$ and $\mathrm{F}$ $(2.39 \pm 0.08)$. There were no significant differences in creatinine level between the control group and group B (tween 20) (2.54 \pm 0.06$)$, group C (MO) (2.42 \pm 0.11$)$, group $\mathrm{E}(\mathrm{Pb}+\mathrm{MO})(2.45 \pm 0.08)$ and group $\mathrm{F}$ $(\mathrm{MO}+\mathrm{Pb})(2.39 \pm 0.08)$.

\section{Plasma albumin level in control and treated group}

As shown in the Figure 2 below, there was no significant difference in albumin levels between the control group and groups B (tween 20) (19.39 \pm 0.23$), \mathrm{C}(\mathrm{MO})(20.19 \pm$ 0.52 ,) $\mathrm{D}(\mathrm{Pb})(18.15 \pm 0.51)$ and $\mathrm{E}(\mathrm{Pb}+\mathrm{MO})$ $(17.49 \pm 0.11)$. The albumin level in group $\mathrm{F}$ $(\mathrm{MO}+\mathrm{Pb})(17.49 \pm 0.11)$ was significantly $(\mathrm{p}$ $<0.05)$ lower compared to group C (MO) $(20.19 \pm 0.52), \mathrm{D}(\mathrm{Pb})(18.15 \pm 0.51)$ and the control group. 


\section{Plasma urea level in control and treated group}

Figure 3 indicates that plasma urea level in control $(14.02 \pm 1.53)$ was significantly ( $\mathrm{p}<0.05$ ) lower compared with plasma urea level in group B (tween 20) $(50.44 \pm 1.75), \mathrm{C}$ (MO) $(58.91 \pm 2.95)$ and $\mathrm{D}(\mathrm{Pb})(56.79 \pm 0.06)$ and significantly higher to that of group $\mathrm{F}$ $(\mathrm{MO}+\mathrm{Pb})(7.48 \pm 1.00)$. Plasma urea level in group B (tween 20) $(50.44 \pm 1.75)$ was slightly lower when compared to that of groups $\mathrm{C}$ (MO) $(58.91 \pm 2.95)$ and $\mathrm{D}(\mathrm{Pb})(56.79 \pm 0.06)$ and was significantly higher than group $\mathrm{F}$ $(\mathrm{MO}+\mathrm{Pb})(7.48 \pm 1.00)$. Also, there was significant decrease in plasma urea level in groups $\mathrm{E}(\mathrm{Pb}+\mathrm{MO})(12.18 \pm 1.45)$ and $\mathrm{F}$ $(\mathrm{MO}+\mathrm{Pb})(7.48 \pm 1.00)$ when compared to that of groups $\mathrm{C}(\mathrm{MO})(58.91 \pm 2.95)$ and $\mathrm{D}(\mathrm{Pb})$ $(56.79 \pm 0.06)$. There was no significant $(\mathrm{p}>$ $0.05)$ deference between plasma urea level in $\mathrm{C}$ (MO) $(58.91 \pm 2.95)$ and $\mathrm{D}(\mathrm{Pb})(56.79 \pm$ 0.06).

\section{Histological staining}

The normal histology of the kidney is clearly seen in the control rats as shown in Plates $1 \mathrm{~A}$ and 2A. The renal cortex shows parts of the renal corpuscle (the Bowman's capsule and the glomerulus), also the proximal convoluted tubules, distal convoluted tubules as well as the urinary space are well preserved. In the urinary space, the parietal layer and the visceral layer of the Bowman capsule are clearly observable. No gross alterations are observed in the morphology of both the proximal and distal convoluted tubules. The lumens in the renal tubules appeared morphologically normal. Treatment with MOLE (group C) and Tween 20 (group B) did not have any effects on the histology of the kidney as seen in Plates $1 \mathrm{~B} \& \mathrm{C}$ and $2 \mathrm{~B}$ $\&$ C. They appear normal and clearly visible with normal appearances. Following administration of lead, as observed in Plates $1 \mathrm{D}$ and 2D, structural alteration in the proximal and distal convoluted tubules are observed and most of the tubules appear occluded without any observable lumen and the number of tubules that are clearly seen are few when compared with control (Plates1A and 2A) and MOLE (Plates $1 \mathrm{C}$ and 2C). The glomeruli appear to be distorted with no observable glomerular space when compared with control and MOLE groups. Plates $1 \mathrm{E}$ and $2 \mathrm{E}$ which are the plates showing group $\mathrm{E}(\mathrm{Pb}+$ MO) show observable tubules, distorted glomerulus with slightly seen urinary space. In Plate $1 \mathrm{~F}$ and $2 \mathrm{~F}$ which show group $\mathrm{F}$ (MO+ $\mathrm{Pb}$ ), it shows some observable tubules with visible lumen as well as occluded lumen. The glomerulus appears distorted with faintly seen urinary space. Also, white plaques formation were observed in groups $\mathrm{D}, \mathrm{E}$ and $\mathrm{F}$ when compared to $\mathrm{A}, \mathrm{B}$, and $\mathrm{C}$ and it appears to be much more pronounced in $\mathrm{D}$ when compared to $\mathrm{E}$ and $\mathrm{F}$. When both $\mathrm{E}$ and $\mathrm{F}$ are compared with each other, it is more pronounced in $\mathrm{F}$ than in $\mathrm{E}$.

\section{Histomorphometric measurement}

Cross sectional area of the glomerulus and the number of glomeruli present in each photomicrograph

Table 4 shows the cross sectional area of the glomerulus and the number of glomeruli present in each photomicrograph. There was no significant difference in the cross sectional area of the glomerulus in both the control and the treated groups. However the glomeruli present in the control group, B (tween 20) and $\mathrm{C}$ (MO) were significantly higher than that of $\mathrm{D}(\mathrm{Pb})$ and $\mathrm{F}(\mathrm{MO}+\mathrm{Pb})$. No significant difference was observed between the control, B (tween 20), C (MO) and $\mathrm{E}(\mathrm{Pb}+\mathrm{MO})$. 
Diameter of the urinary space and cross sectional area of proximal convoluted tubules and (pct) distal convoluted tubules (dct).

Table 5 shows the diameter of the urinary space and the cross sectional area of both the proximal convoluted tubules and distal convoluted tubules in both the control and the treated groups. The diameter of the urinary space in the control was significantly higher when compared with $\mathrm{D}(\mathrm{Pb})$. The urinary space diameter in B (tween 20), C (MO), $\mathrm{E}(\mathrm{Pb}+\mathrm{MO})$ and $\mathrm{F}(\mathrm{MO}+\mathrm{Pb})$ was significantly higher than that of $\mathrm{D}(\mathrm{Pb})$. No significant difference was observed between the control and groups B (tween 20), C (MO), $\mathrm{E}(\mathrm{Pb}+\mathrm{MO})$ and $\mathrm{F}(\mathrm{MO}+\mathrm{Pb})$. Also, the cross sectional area of both the proximal convoluted tubules and distal convoluted tubules in the control was significantly higher when compared with $\mathrm{D}(\mathrm{Pb})$. The cross sectional area of both the proximal convoluted tubules and distal convoluted tubules in $\mathrm{B}$ (tween 20), C (MO), E (Pb + MO) and F (MO $+\mathrm{Pb}$ ) were significantly higher than that of $\mathrm{D}$ $(\mathrm{Pb})$. No significant difference was observed between the control and groups B (tween 20), $\mathrm{C}(\mathrm{MO}), \mathrm{E}(\mathrm{Pb}+\mathrm{MO})$ and $\mathrm{F}(\mathrm{MO}+\mathrm{Pb})$.

Table 1: Mean body weight gain of control and treated rats.

\begin{tabular}{lccc}
\hline Groups & $\begin{array}{c}\text { Initial (average) body } \\
\text { weight }(\mathbf{g})\end{array}$ & $\begin{array}{c}\text { Final ( average) } \\
\text { body weight }(\mathbf{g})\end{array}$ & Weight gain (g) \\
\hline $\mathrm{A} \mathrm{CONTROL}$ & 116.00 & 209.00 & $93.00 \pm 7.00$ \\
$\mathrm{~B}(\mathrm{TWEEN} 20)$ & 155.00 & 195.00 & $40.00 \pm 3.54^{*}$ \\
$\mathrm{C}(\mathrm{MO})$ & 151.00 & 193.00 & $42.00 \pm 8.60^{*}$ \\
$\mathrm{D}(\mathrm{Pb})$ & 149.00 & 178.00 & $29.00 \pm 7.48^{*}$ \\
$\mathrm{E}(\mathrm{Pb}+\mathrm{MO})$ & 167.00 & 213.00 & $46.00 \pm 11.45^{*}$ \\
$\mathrm{~F}(\mathrm{MO}+\mathrm{Pb})$ & 185.00 & 201.00 & $16.00 \pm 5.34^{*}$ \\
\hline Values are mean $\pm \mathrm{SEM}$ of data obtained, * $=$ significantly different from control, $\mathrm{P}$ values: $(\mathrm{p}<0.05)$, Moringa \\
oleifera $(\mathrm{MO})$, Lead $(\mathrm{Pb})$, Lead + Moringa oleifera $(\mathrm{Pb}+\mathrm{MO})$, Moringa oleifera + Lead $(\mathrm{MO}+\mathrm{Pb})$.
\end{tabular}

Table 2: Food intake of rats in the first and last week of treatment.

\begin{tabular}{lcc}
\hline Groups & First week of treatment $(\mathbf{g})$ & Last week of treatment $(\mathbf{g})$ \\
\hline $\mathrm{A}$ CONTROL & $24.00 \pm 0.71$ & $18.00 \pm 0.95$ \\
$\mathrm{~B}(\mathrm{TWEEN} \mathrm{20)}$ & $26.80 \pm 0.86^{*}$ & $16.00 \pm 0.45$ \\
$\mathrm{C}(\mathrm{MO})$ & $26.40 \pm 0.75^{*}$ & $18.00 \pm 0.95$ \\
$\mathrm{D}(\mathrm{Pb})$ & $29.20 \pm 0.86^{*}$ & $13.00 \pm 0.32 *^{\# \mathrm{a}}$ \\
$\mathrm{E}(\mathrm{Pb}+\mathrm{MO})$ & $28.60 \pm 0.51^{*}$ & $14.00 \pm 0.84^{*^{\mathrm{a}}}$ \\
$\mathrm{F}(\mathrm{MO}+\mathrm{Pb})$ & $27.60 \pm 0.40^{*}$ & $14.00 \pm 0.84^{\mathrm{a}}$ \\
\hline Values are mean \pm SEM of data obtained; = Significantly different from control; \# = significantly different with \\
$\mathrm{B}(\mathrm{Tween} 20) ;{ }^{a}=$ significantly different compare to C $(\mathrm{MO}) ; \mathrm{P}$ values: $(\mathrm{p}<0.05)$, Moringa oleifera $(\mathrm{MO})$, \\
Lead $(\mathrm{Pb})$, Lead + Moringa oleifera $(\mathrm{Pb}+\mathrm{MO})$, Moringa oleifera + Lead $(\mathrm{MO}+\mathrm{Pb})$.
\end{tabular}


Table 3: Water intake of rats the first and last week of treatment.

\begin{tabular}{lcc}
\hline Groups & First week of treatment $(\mathbf{m l})$ & Last week of treatment $(\mathbf{m l})$ \\
\hline A CONTROL & $70.00 \pm 0.84$ & $30.00 \pm 0.32$ \\
$\mathrm{~B}(\mathrm{TWEEN} \mathrm{20)}$ & $70.00 \pm 0.84$ & $36.00 \pm 0.84^{*}$ \\
$\mathrm{C}(\mathrm{MO})$ & $72.00 \pm 0.71$ & $32.00 \pm 0.89^{\#}$ \\
$\mathrm{D}(\mathrm{Pb})$ & $51.00 \pm 0.32^{* \mathrm{ab}}$ & $20.00 \pm 0.71^{* \mathrm{a}}$ \\
$\mathrm{E}(\mathrm{Pb}+\mathrm{MO})$ & $40.00 \pm 0.40^{* \# \mathrm{a}}$ & $24.00 \pm 0.71^{* \mathrm{ab}}$ \\
$\mathrm{F}(\mathrm{MO}+\mathrm{Pb})$ & $66.00 \pm 0.71^{* \mathrm{abc}}$ & $24.00 \pm 0.71^{* \mathrm{ab}}$ \\
\hline
\end{tabular}

Values are mean \pm SEM of data obtained; * $=$ Significantly different from control; \# = significantly different with $\mathrm{B}$ (Tween 20); ${ }^{\mathrm{a}}=$ significantly different compare to $\mathrm{C}(\mathrm{MO}) ;{ }^{\mathrm{b}}=$ significantly different with $\mathrm{D}(\mathrm{Pb}) ;{ }^{\mathrm{C}}=$ significantly different with $\mathrm{E}(\mathrm{Pb}+\mathrm{MO})$.; $\mathrm{P}$ values: $(\mathrm{p}<0.05)$, Moringa oleifera $(\mathrm{MO})$, Lead $(\mathrm{Pb})$, Lead + Moringa oleifera $(\mathrm{Pb}+\mathrm{MO})$, Moringa oleifera $+\mathrm{Lead}(\mathrm{MO}+\mathrm{Pb})$.

Table 4: Cross sectional area of the glomerulus and Number of glomeruli present in each photomicrograph.

\begin{tabular}{lcc}
\hline Groups & $\begin{array}{c}\text { Cross sectional area of the } \\
\text { glomerulus }(\mathbf{m m})\end{array}$ & $\begin{array}{c}\text { Number of glomeruli present in } \\
\text { each photomicrograph }\end{array}$ \\
\hline A control & $0.60 \pm 0.08$ & $15.00 \pm 0.58$ \\
$\mathrm{~B}($ tween20) & $0.59 \pm 0.13$ & $11.00 \pm 1.00$ \\
$\mathrm{C}(\mathrm{MO})$ & $1.02 \pm 0.12$ & $12.00 \pm 1.00$ \\
$\mathrm{D}(\mathrm{Pb})$ & $0.79 \pm 0.15$ & $6.00 \pm 1.53 * \#^{\mathrm{a}}$ \\
$\mathrm{E}(\mathrm{Pb}+\mathrm{MO})$ & $0.79 \pm 0.15$ & $9.67 \pm 2.33$ \\
$\mathrm{~F}(\mathrm{MO}+\mathrm{Pb})$ & $0.62 \pm 0.03$ & $5.00 \pm 0.58^{\mathrm{a}} \#^{\mathrm{a}}$ \\
\hline
\end{tabular}

Values are mean \pm SEM of data obtained. $*=$ Significantly different from control; \# = significantly different from $\mathrm{B}$; $\mathrm{a}=$ significantly different from C; P values: $(\mathrm{p}<0.05)$, Moringa oleifera $(\mathrm{MO})$, Lead $(\mathrm{Pb})$, Lead + Moringa oleifera $(\mathrm{Pb}+\mathrm{MO})$, Moringa oleifera $+\mathrm{Lead}(\mathrm{MO}+\mathrm{Pb})$.

Table 5: Diameter of the urinary space and cross sectional area of proximal convoluted tubules and (PCT) distal convoluted tubules (DCT).

\begin{tabular}{lccc}
\hline Groups & $\begin{array}{c}\text { Diameter of the } \\
\text { urinary space }\end{array}$ & $\begin{array}{c}\text { Cross sectional area } \\
\text { of PCT }\end{array}$ & $\begin{array}{c}\text { Cross sectional } \\
\text { area of DCT }\end{array}$ \\
\hline A CONTROL & $0.09 \pm 0.00$ & $0.05 \pm 0.01$ & $0.02 \pm 0.00$ \\
$\mathrm{~B}(\mathrm{TWEEN} \mathrm{20)}$ & $0.11 \pm 0.01$ & $0.06 \pm 0.01$ & $0.04 \pm 0.01$ \\
$\mathrm{C}(\mathrm{MO})$ & $0.11 \pm 0.02$ & $0.05 \pm 0.01$ & $0.03 \pm 0.01$ \\
$\mathrm{D}(\mathrm{Pb})$ & $0.00 \pm 0.00 * \#^{\mathrm{abc}}$ & $0.00 \pm 0.01 * \#^{\mathrm{abc}}$ & $0.00 \pm 0.00^{\mathrm{abc}}$ \\
$\mathrm{E}(\mathrm{Pb}+\mathrm{MO})$ & $0.07 \pm 0.00$ & $0.04 \pm 0.01$ & $0.02 \pm 0.00$ \\
$\mathrm{~F}(\mathrm{MO}+\mathrm{Pb})$ & $0.07 \pm 0.01$ & $0.07 \pm 0.01$ & $0.02 \pm 0.01$ \\
\hline
\end{tabular}

Values are mean \pm SEM of data obtained, $*=$ Significantly different from control; \# = significantly different from $\mathrm{B}$ (Tween 20); ${ }^{\mathrm{a}}=$ significantly different from $\mathrm{C}(\mathrm{MO}) ;{ }^{\mathrm{b}}=$ significantly different from $\mathrm{E}(\mathrm{Pb}+\mathrm{MO}) ;{ }^{\mathrm{b}}=$ significantly different from $\mathrm{F}(\mathrm{MO}+\mathrm{Pb}, \mathrm{P}$ values: $(\mathrm{p}<0.05)$, Moringa oleifera $(\mathrm{MO})$, Lead $(\mathrm{Pb})$, Lead + Moringa oleifera $(\mathrm{Pb}+\mathrm{MO})$, Moringa oleifera + Lead $(\mathrm{MO}+\mathrm{Pb})$. 


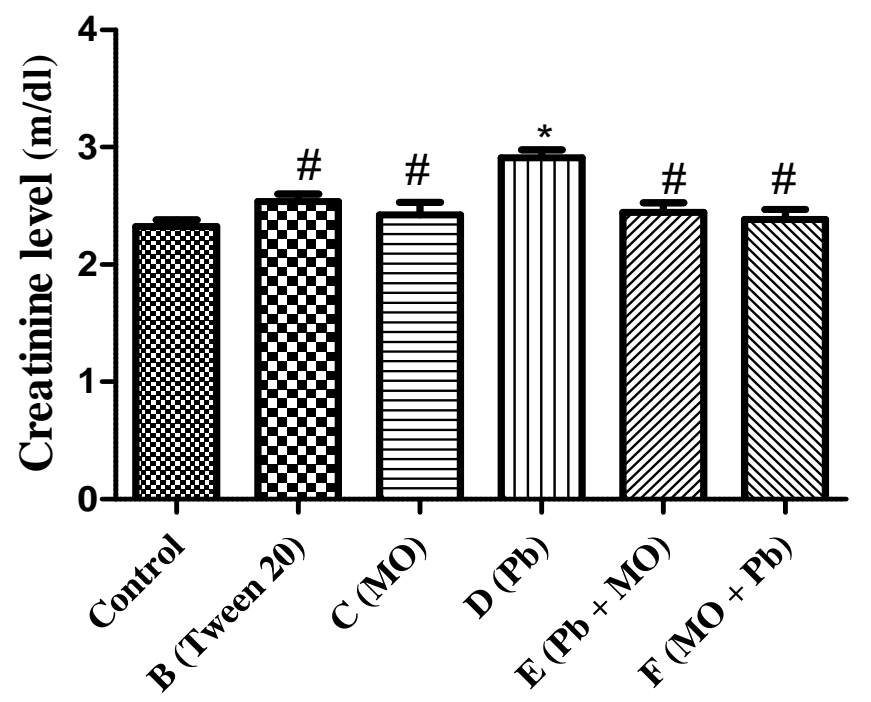

Figure 1: Plasma creatinine level $(\mathrm{mg} / \mathrm{dl})$. Values are mean \pm SEM of data obtained; $*$ = Significantly different from control; \# = significantly different from $\mathrm{D}(\mathrm{Pb})$; P values: $(\mathrm{p}<0.05)$, Moringa oleifera $(\mathrm{MO})$, Lead $(\mathrm{Pb})$, Lead + Moringa oleifera $(\mathrm{Pb}+\mathrm{MO})$, Moringa oleifera $+\mathrm{Lead}(\mathrm{MO}+\mathrm{Pb})$.

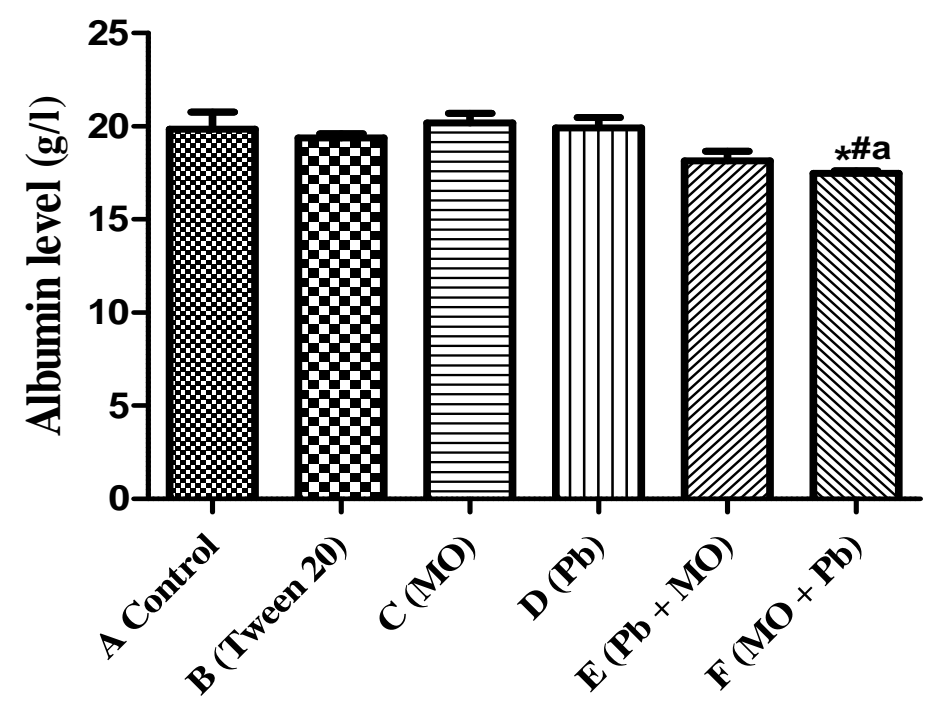

Figure 2: Plasma albumin level $(\mathrm{g} / \mathrm{l}) . *$ = Significantly different from $\mathrm{C}$; \# = significantly different from control $\mathrm{a}=$ significantly different from D; P values: $(\mathrm{p}<0.05)$, Moringa oleifera $(\mathrm{MO})$, Lead $(\mathrm{Pb})$, Lead + Moringa oleifera $(\mathrm{Pb}+\mathrm{MO})$, Moringa oleifera $+\mathrm{Lead}(\mathrm{MO}+\mathrm{Pb})$. 


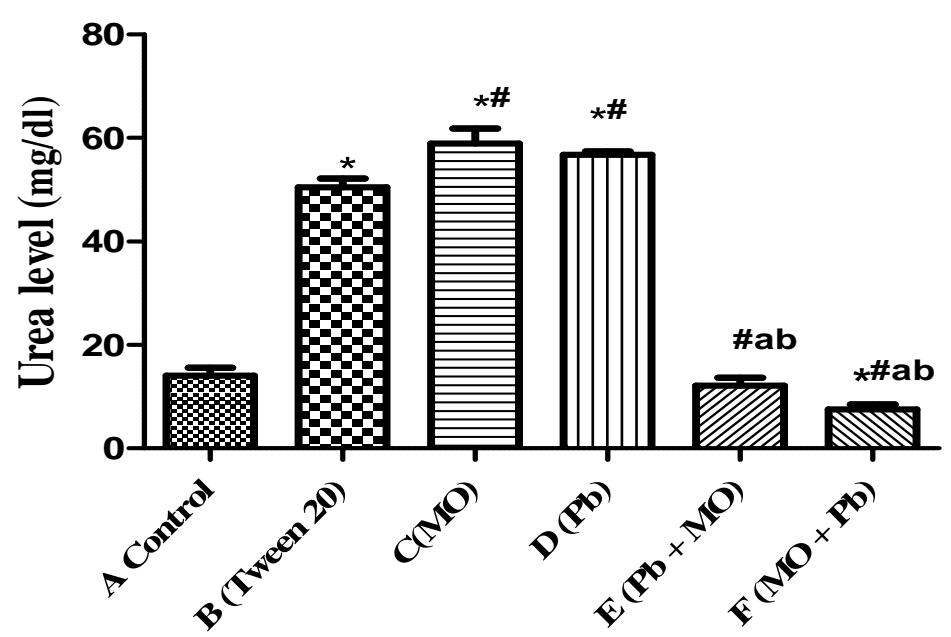

Figure 3: Plasma urea level (mg/dl). * = Significantly different from Control; \# = significantly different from B (tween 20); ${ }^{\mathrm{a}=}$ significantly different from $\mathrm{C}(\mathrm{MO}) ;{ }^{\mathrm{b}}=$ significantly different from $\mathrm{D}(\mathrm{Pb}) ; \mathrm{P}$ values: $(\mathrm{p}<0.05)$, Moringa oleifera $(\mathrm{MO})$, Lead $(\mathrm{Pb})$, Lead + Moringa oleifera $(\mathrm{Pb}+\mathrm{MO})$, Moringa oleifera + Lead $(\mathrm{MO}+\mathrm{Pb})$.

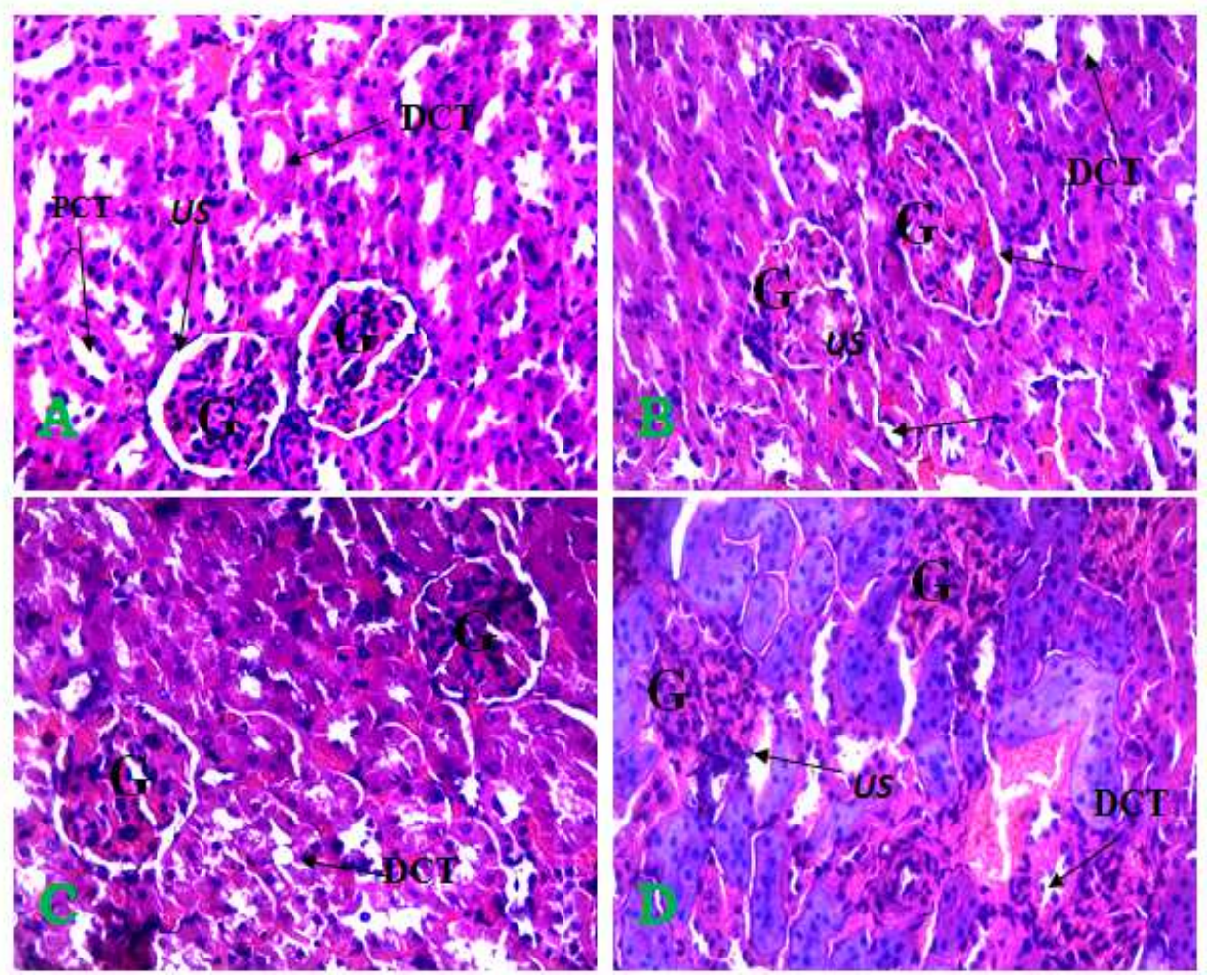



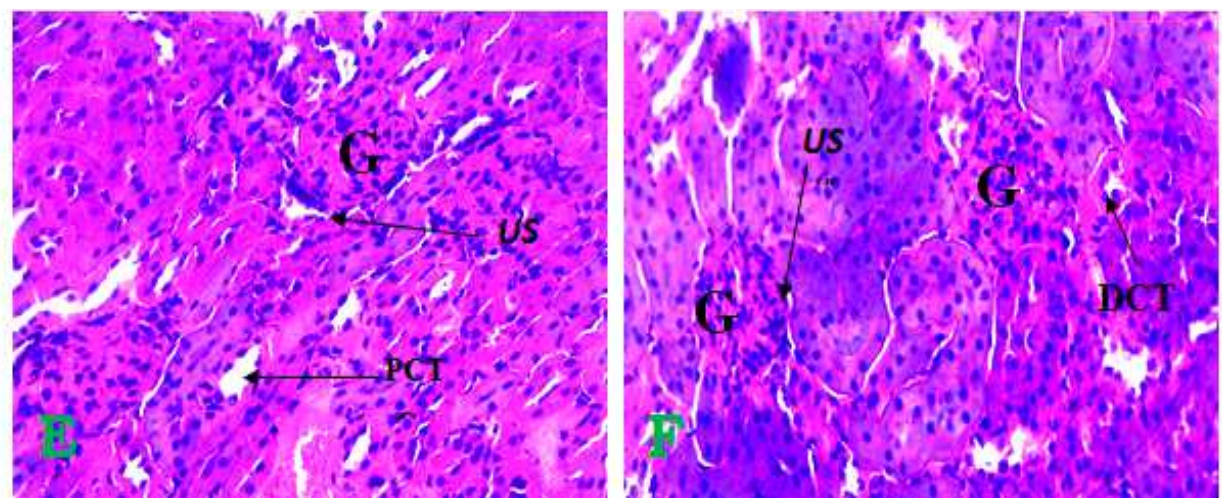

Plate 1: Photomicrograph sections of the kidney. A (Control), B (Tween 20), C (MO), D ( $\mathrm{Pb}), \mathrm{E}(\mathrm{Pb}+\mathrm{MO}), \mathrm{F}$ $(\mathrm{MO}+\mathrm{Pb})$; G - glomerulus, PCT - proximal convoluted tubules, DCT - distal convoluted tubules, US - urinary space. H\&E $\mathrm{X} 400$. Moringa oleifera $(\mathrm{MO})$, Lead $(\mathrm{Pb})$, Lead + Moringa oleifera $(\mathrm{Pb}+\mathrm{MO})$, Moringa oleifera $+\mathrm{Lead}(\mathrm{MO}+\mathrm{Pb})$.
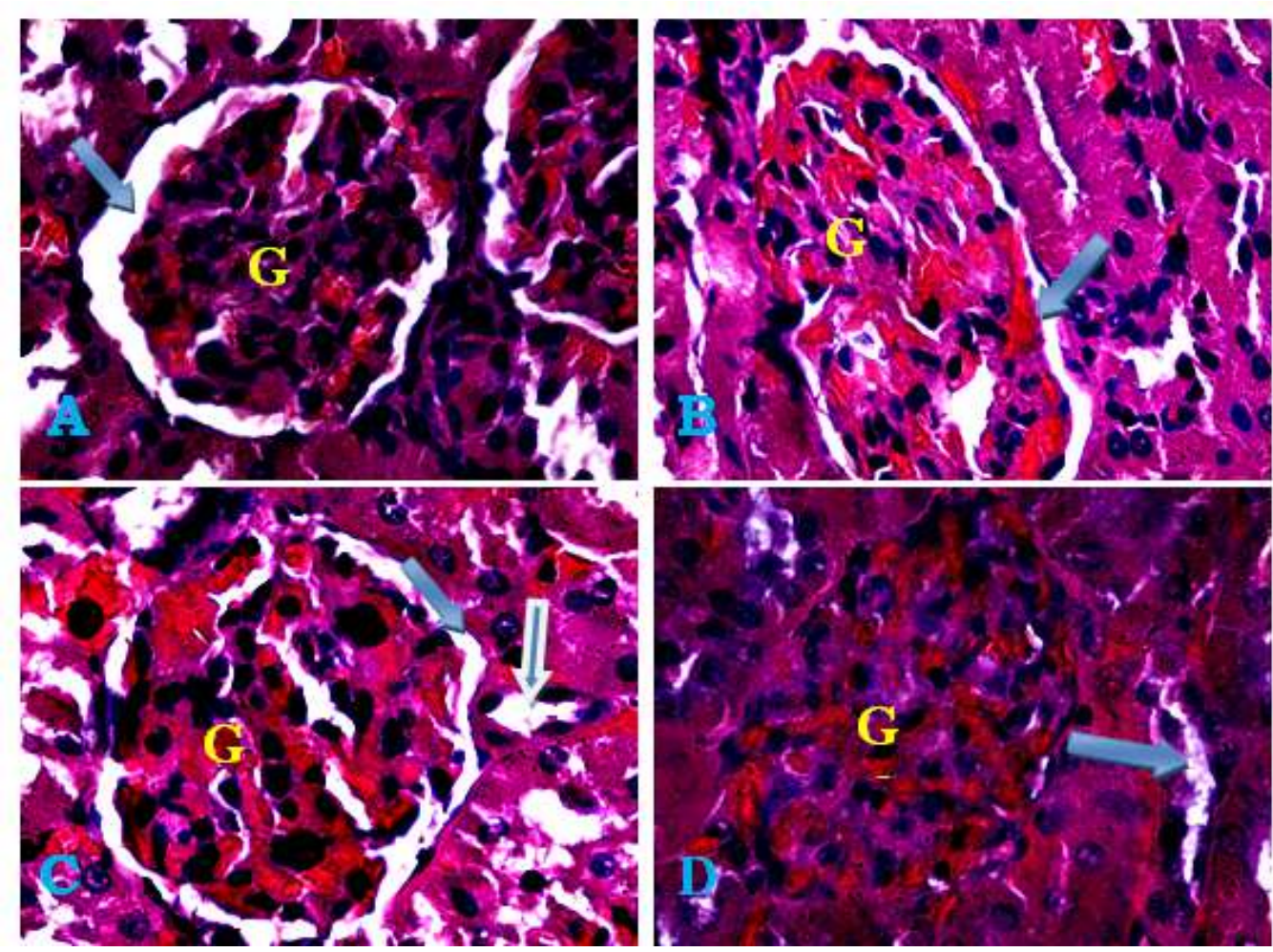

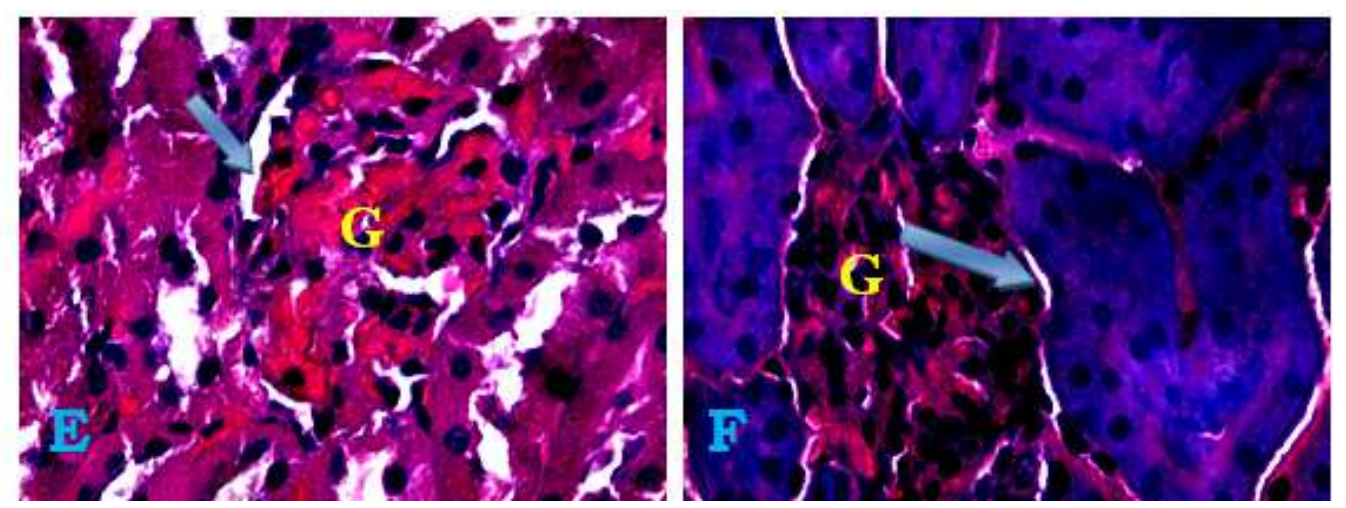

Plate 2: Photomicrograph sections of the kidney. A (Control), B (Tween 20), C (MO), D ( $\mathrm{Pb}), \mathrm{E}(\mathrm{Pb}+\mathrm{MO}), \mathrm{F}$ $(\mathrm{MO}+\mathrm{Pb}) ; \mathrm{G}$ - glomerulus, thin blue arrow -urinary convoluted tubules, thick blue arrow - urinary space. H\&E X1000. Moringa oleifera $(\mathrm{MO})$, Lead $(\mathrm{Pb})$, Lead + Moringa oleifera $(\mathrm{Pb}+\mathrm{MO})$, Moringa oleifera $+\mathrm{Lead}(\mathrm{MO}+\mathrm{Pb})$.

\section{DISCUSSION}

This study investigated the microanatomy and histomorphometry analysis of the effects of Moringa oleifera leaf extract on some markers of renal function and histoarchitecture of the kidney in rats with lead-induced kidney injury. A significant decrease in food consumption was observed in the $\mathrm{Pb}$ treated group when compared with the control rats. This was accompanied by a reduction in body weight. This may have resulted from loss of appetite and muscle weakness caused by lead exposure in the body (Oscar, 2010) or as a result of depression of feeding center located in the ventromedial nucleus of the hypothalamus (Guyton and Hall, 2006). This needs to be investigated further. This is in agreement with other study (Djebli et al., 2004). Similarly, the water intake of the experimental animals fell significantly when compared with the control rats. This could be attributed to the depression of thirst center located in the lateral hypothalamus (Guyton and Hall, 2006) or altered states of consciousness caused by lead.

In the present study, plasma creatinine and urea levels were significantly higher in the $\mathrm{Pb}$ group when compared with the control rats and other experimental groups which is an indication of impaired renal function. This is in contrast to Dioka et al. (2004), who reported that occupational lead exposure did not have any effect on electrolytes, urea and creatinine levels. Plasma urea and creatinine are the most sensitive biochemical markers used in the assessment of renal tissue damage, because urea and creatinine are excreted through the kidneys. Therefore, in cellular damage, there is retention of urea and creatinine in the blood (Ganong, 2009). The significant increase in plasma concentration of creatinine is an evidence of reduced ability of the renal tubules to extract and remove creatinine from the plasma of the experimental groups, a fact that was also supported by the photomicrographs of the kidney tissue. The results seen in group $\mathrm{E}(\mathrm{Pb}$ $+\mathrm{MO})$ and $\mathrm{F}(\mathrm{MO}+\mathrm{Pb})$ give an indication that Moringa oleifera has protective and ameliorative effects on lead-induced kidney damage as revealed by reduced plasma creatinine levels. This is in accordance with the findings of Lakshmana et al. (2013), who reported that Moringa oleifera was found to be an effective herbal medicine in animal models of renal failure. There were no 
significant differences in creatinine concentration between the control rats and groups that were administered tween 20 solution and Moringa oleifera only. This shows that $M$. oleifera and tween 20 solution do not have any adverse effects on the kidney.

The increase in plasma urea level in group B compared with the control may be as a result of diminished protein synthesis in group B. Albumin is produced in the liver and is one of the most abundant protein in blood plasma, a proper balance of albumin is required to keep fluid from leaking out of blood vessels. Albumin also carries vital nutrients, hormones, and proteins required to clot blood properly (Sembulingam, 2012). If the liver and/or kidneys are not functioning properly, serum albumins will not be at their normal levels (Sembulingam, 2012). In this study, there was no significant difference in albumin level between the control group and groups B (tween 20), C (MO), D (Pb) and E $(\mathrm{Pb}+\mathrm{MO})$. The albumin level in group $\mathrm{F}$ $(\mathrm{MO}+\mathrm{Pb})$ was significantly lower compared to group $\mathrm{C}(\mathrm{MO}), \mathrm{D}(\mathrm{Pb})$ and the control group. The effect of lead exposure on the serum protein levels is controversial; Dioka et al. (2004), Pachathundikandi et al. (2006), and Herman et al. (2009) observed no change in serum albumin level in automobile workers and albino rats exposed to long-term moderate lead concentrations. Histological and histochemical results of this study clearly support earlier reports that, lead has nephrotoxic effect on renal tissue and lead poisoning is associated with oxidative stress in blood and brain tissues (Adewole and Ayoka, 2009). The formation of intracellular inclusion bodies is a major sign of chronic lead intoxication (Muntner et al., 2003) and their accumulation is an early mark of lead intoxication nephropathy.

In the present study, the photomicrographs of the control group, groups B and C showed normal histology of the kidney, with the renal corpuscle and the interstitium showing clearly observable features of the kidney histoarchitecture such as normal renal cortex which shows parts of the renal corpuscle (the Bowman's capsule and the glomerulus), also the proximal convoluted tubules, distal convoluted tubules as well as the urinary space are easily identified. In the urinary space, the parietal layer and the visceral layer of the Bowman capsule are clearly observable. This is an indication that ethanolic extract of Moringa oleifera leaf does not have any adverse effects on kidney structure and function and this is in conformity with Lakshmana et al. (2013), who reported that Moringa oleifera has no toxic effects or undesired properties on the kidney. Adedapo et al. (2009) also reported no toxicity following treatment with aqueous extract of $M$. oleifera taken orally at 400, 800, 1600 , and $2000 \mathrm{mg} / \mathrm{kg} / \mathrm{bw}$. However, this is in contrast to Ayi Vandi et al. (2012) who reported that Moringa oleifera extract had adverse effect on the kidney.

In this study, following administration of lead, as observed in plates 1D and 2D, structural alterations in the proximal and distal convoluted tubules were observed and most of the tubules appear occluded without any observable lumen and the numbers of tubules which can be seen clearly are few. The glomeruli appear to be distorted with no observable glomerular space and white plaques formations were also observed. One of the major adverse effects of lead on the kidney includes nephritis (glomerulonephritis and interstitial nephritis) as well as renal insufficiency. Glomerulonephritis is an inflammation of the glomerulus and it is often caused by infections, toxic substances such as lead and autoimmune diseases (Lin et al., 2001). One of its complications is the disturbance of glomerular structure with an 
inflammatory cell proliferation. Also, the white plaques formations that were observed in the lead group can be as a result of proximal tubular nephropathy, glomerular sclerosis and interstitial fibrosis. These are common features of lead on the kidney histoarchitecture. A similar finding was reported by Diamond (2005), that lead nephrotoxicity is characterized by proximal tubular nephropathy, glomerular sclerosis and interstitial fibrosis. A few studies have revealed histopathological features of renal injury in humans, including intranuclear inclusion bodies and cellular necrosis in the proximal tubules and interstitial fibrosis (Missoun et al., 2010). In this study, Plates $1 \mathrm{E}$ and $2 \mathrm{E}$ showing group $\mathrm{E}(\mathrm{Pb}+\mathrm{MO})$ showed observable tubules, distorted glomerulus with slightly seen urinary space. This is an indication that Moringa oleifera was able to ameliorate the kidney damage done by lead administration. This was supported by the results of plasma creatinine level and histomorphometry analysis in Moringa group and group $\mathrm{E}(\mathrm{Pb}+\mathrm{MO})$. Furthermore, some observable tubules with visible lumen as well as occluded lumen with distorted glomerulus that appear faintly are seen in group $\mathrm{F}$ (MO+PB) shows that Moringa oleifera does not make the kidney resilient to toxic agent as much as it facilitates regeneration resulting from nephrotoxic substances. The nephroprotective property of Moringa oleifera could be due to the high concentration of flavonoid and alkaloid it contain (Olagunju et al., 2009).

\section{Conclusion}

In conclusion, the results of this study indicated that lead exposure on the kidney of rats, induced nephrotoxicity which manifested as renal tissue damage, elevated level of plasma creatinine resulting from impaired renal function and Moringa oleifera leaf extract has ameliorative and protective properties on lead-induced kidney injury. However, Moringa oleifera was better as ameliorative agent rather than prophylactic agent in rats in lead-induced kidney damage. In view to the observations from this study, we recommend further study into the antioxidant properties of Moringa oleifera leaf extract in lead induced nephrotoxicity.

\section{REFERENCES}

Adedapo AA, Mogbojuri OM, Emikpe BO. 2009. Safety evaluations of the aqueous extract of the leaves of Moringa oleifera in rats. J. Med. Plant, 3: 586-591.

Adekunle I, Akinyemi M. 2004. Lead levels of certain consumer products in Nigeria: a case study of smoked fish foods from Abeokuta. Food and Chemical Toxicology, 42(9): 1463- 1468.

Adewole OS, Ayoka AO. 2009. Beneficial Role of Quercetin on Developmental Brain of Rats Against Oxidative StressInduced By Lead Poisoning. Pharmacologyonline, 2: 1171-1184.

Ahmed K, Gonfa A, Ephrem E. 2008. Lead exposure study among workers in lead acid battery repair units of transport service enterprises, Addis Ababa, Ethiopia: across-sectional study. Journal of Occupational Medicine and Toxicology, 3; 30.

Ajayi OM, Odusanya AE. 2014. A Review Paper on Lead Exposure and Poisoning in Nigerian Children: The way forward. Elixir International Journal of Pollution, 70: 23808-23811.

Anthony LM. 2010. Junquira's Basic Histology Text and Atlas (12th edn). Publish by The McGraw-Hill Companies.

Anwar F, Latif S, Ashraf M, Gilani AH. 2007. Moringa oleifera: a food plant with multipurpose medicinal uses. J. Agric. Food Chem., 51: 6558-6563. 
Ayi VK, Shehu UH, Abdul-Ganiyu A. 2012. Subacute Toxicity Studies of Moringa oleifera Leaf. New York Science Journal, 5(1): 71-84.

Diamond GL. 2005. Risk assessment of nephrotoxic metals, the toxicology of the kidney. Risk Anal., 25: 169-178.

Dioka CE, Orisakwe OE, Adeniyi FA, Meludu SC. 2004. Liver and Renal function tests in Artisans occupationally exposed to lead in mechanic village in Nnewi, Nigeria. Int J Environ Res. Public Health, 1; 21-25.

Djebli N, Slimani M, Aoues A. 2004. Effect of lead exposure on dopaminergic transmission in the rat brain. JournalToxicology, 207(3): 363-368.

Green RE, Pain DJ. 2012. Potential health risks to adults and children in the UK from exposure to dietary lead in game birds shot with lead ammunition. Food and Chemical Toxicology, 50(11): 41804190.

Guyton AC, Hall JE. 2006. Textbook of Medical Physiology $\left(11^{\text {th }}\right.$ edn $)$ WB Saunders Company: Philadelphia, Pennsylvania.

Ganong WF, 2009. Review of Medical Physiology (23rd edn). Mc Graw-Hill: New York.

Herman DS, Geraldine M, Venkatesh T. 2009. Influence of minerals on lead-induced alterations in, liver function in rats exposed to long-term lead exposure. Journal of Hazardous Materials, 166: 1410-1414.

Lakshmana G, Rajeshkumar D, Ashok RP, Anil KM, Kiran KM, Divya VC, Divya C, Ram SKB. 2013. Determination of Nephroprotective Activity of Ethanolic Leaf Extract of Moringa pterygosperma on Paracetamol induced Nephrotoxic Rats. International Journal of Allied
Medical Sciences and Clinical Research, 1(2): 51-61.

Lin JL, Tan DT, Hsu KH, Yu CC. 200. Environmental lead exposure and progressive renal insufficiency. Arch Intern Med., 161(2): 264-271.

Lo YC, Dooyema CA, Neri A, Durant J, Jefferies T, Menina-Marino A, Deravello L, Throughman D, Davis L, Dankoli RS, Samson MY, Ibrahim LM, Okechukwu O, Umar-Tsafe NT, Dama AH, Brown MJ. 2012. Childhood lead poisoning associated with gold ore processing. Environmental Health Perspectives, 120(10): 1450-1455.

Maduabuchi J, Nzegwu C, Adigba E, Aloke R., Ezomike C, Okocha C, Obi E, Orisakwe O. 2006. Lead and cadmium exposures from canned and non-canned beverages in Nigeria: a public health concern. Science of the Total Environment, 366(2): 621-626.

Missoun F, Slimani M, Aoues A. 2010. Toxic effect of lead on kidney function in rat Wistar. African Journal of Biochemistry Research, 4(2): 21-27.

Muntner P, He J, Vupputuri S, Coresh J, Batuman V. 2003. Blood lead and chronic kidney disease in the general United States population. Kidney International, 63: 1044-1050.

Nnorom IC, Osibanjo O, Eleke C. 2006. Evaluation of Human Exposure to Lead and Cadmium from Some Local Nigerian Medicinal Preparations. Journal of Applied Sciences, 6(14): 2907-2911.

Olagunju JA, Adeneye AA, Fagbohunka BC, Bisuga NA, Ketiku AO, Benebo AS, Olufowobi OM, Adeoye AG, Alimi MA, Adeleke AG, 2009. Nephroprotective activities of the aqueous seed extract of Carica papaya Linn in carbon tetrachloride induced renal injured Wistar 
rats: a dose- and time-dependent study. Biology and Medicine, 1(1): 11-19.

Orisakwe OE, Igwilo IO, Afonne OJ, Maduabuchi, JU, Obi E, Nduka JC, 2006. Heavy metal hazards of sachet water in Nigeria. Archives of Environmental \& Occupational Health, 61(5): 209-213.

Oscar T. 2010. Agency for Toxic Substances and Disease Registry. Lead Toxicity; Case Studies in Environmental Medicine. US Department of Health and Human Services, Public Health Service: Atlanta.

Owolabi JO, Opoola E, Caxton-Martins EA. (2012). Healing and Prophylactic Effects of Moringa oleifera Leaf Extract on Lead Induced Damage to Haematological and Bone Marrow Elements in Adult Wistar Rat Models. Open Access Scientific Reports, 1(8): 385-389.
Pachathundikandi SK, Veghese ET. 2006. Blood zinc protoporphyrin serum total protein and total cholesterol levels in Automobile workers in relation to lead Toxicity our experience. Indian J. Clin. Biochem., 21(2): 114-117.

Pfitzner MA, Thacher TD, Petitfor, JM, Zoakah A, Lawson JO, Fischer PR. 2000. Prevalence of elevated blood lead levels in Nigerian children. Ambulatory Child Health, 6(2): 115-123.

Robert A, Thomas W. 2001. Toxic Effects of Metals. Toxicology: The Basic Science of Poisons $\left(6^{\text {th }}\right.$ edn) McGraw-Hill: New York.

Sembulingam K, Prema S. 2012. Essentials of Medical Physiology (6th edn). Jaypee Brothers Medical Publishers. 